\title{
Networks, Social Capital, and Social Liability: The Case of Pakistani ISI, the Taliban and the War against Terrorism
}

\author{
Shaul M. Gabbay \\ Josef Korbel School of International Studies, University of Denver, Denver, CO, USA \\ Email: shaul.gabbay@du.edu \\ Received 10 August 2014; revised 16 September 2014; accepted 9 October 2014 \\ Copyright (c) 2014 by author and Scientific Research Publishing Inc. \\ This work is licensed under the Creative Commons Attribution International License (CC BY). \\ http://creativecommons.org/licenses/by/4.0/ \\ c) (i) Open Access
}

\begin{abstract}
Pakistan is one of the most important players as well as a playground frontier of the global war on terrorism beginning from September 11 to the present. In this paper we delineate the complexities of the war against terrorism taking a social network approach. The paper argues that one of the main challenges for fighting terrorism in places such as Pakistan is the social network ties which exit between the different constituencies, sometimes constituencies which are seemingly on opposing sides. The paper uses social capital of organizations to map the capital and liabilities of strong and weak ties between the Pakistani intelligence service (ISI) and the Taliban and how they change over time.
\end{abstract}

\section{Keywords}

Pakistan, ISI, Taliban, Social Networks, Social Capital

\section{Introduction}

With nearly clockwork precision, when Pakistan is addressed in the news and even within academic circles, the issue of terrorism inevitably comes up. And for some, discussions of terrorism as a ubiquitous aspect of Pakistani politics and society have become something rather prosaic, akin to an unimaginative and predictable movie. At the same time, however, it really is impossible to discuss Pakistan in any meaningful way without addressing the issue of terrorism, not just in relation to its own society, but also as a broader picture concerning international security.

After September 11, groups such as the Taliban and al Qaeda became household names, often without a deeper understanding of who they actually were, let alone where they operated, and what their goals were (be- 
yond "destroying the infidel”). Although these groups had been known and studied for years, an immediate need to produce information about them often led to more confusion rather than clarity. Issues became scrambled. For one, individual nations (Pakistan, Afghanistan, Iran, Iraq, etc.) seemingly began to evaporate into a fantastically dark grouping of Islamist states with no other identity than that of "enemy". Likewise, the Taliban and al Qaeda became synonymous, bound by the notion of jihad, which again, was superficially translated as a religious justification for the killing of innocent people.

Since that time, after the dust had both literally and figuratively settled, a great deal of progress has been made in not only defining the threats, but also in terms of searching out solutions to the problem at hand. During the past 13 years, we have witnessed the production of competent arguments emanating from various academic perspectives. Where, once upon a time the issue of terrorism had been the realm of political science and IR theorists, prominent psychologists, sociologists, and anthropologists more earnestly began to assert that terrorism needed to be viewed through a prism that focused not simply on strategic politics (based on the rational-choice model of international relations), but also in terms of a new explanation of "politics" carried out through unconventional means (based upon religiously and socially constructed visions of justice), which are not necessarily congruent with "modern" perceptions of conflict and cooperation.

We began to see the rise of theories from individuals such as Stephen Borgatti, Valdis Krebs, Marc Sageman, and Kathleen Carley (to name a few), who focused on terrorism from the social level, addressing how terrorist groups form and operate structurally. Many of these more recent works, particularly that of Marc Sageman [1] attempted to take a scientific approach to understanding terrorism as a whole. And while these works remain valuable in terms of understanding international terrorism and the global jihad, in-depth, country-specific analysis has been somewhat overlooked (although obviously not entirely ignored).

As such, this paper is an attempt to build upon these studies and to analyze the situation in one particular country-Pakistan. By limiting the scope within the boundaries of a specific nation, we can look at terrorism within the confines of a particular society, and how it allows for terrorist networks to thrive on a local level with implications for how they operate across borders. Also by restraining our analysis, we are also able to address a specific government-a product of a specific society—and its action (or inaction) when it comes to combating terrorism. In this vein, two key events that occurred in 2011 guide the inquiry of this paper. First was the assassination of Punjab Governor Salman Taseer, who was killed by one of his own bodyguards. Second is the capture and killing of Osama bin Laden on Pakistani soil.

The assassination of Taseer naturally begs a paradoxical chain of interrelated questions. Was this a singular act of terrorism, carried out by an individual bent on punishing his superior for his perceived immoral stance on the blasphemy laws? What ultimately guided his actions? Was it his allegiance to a higher preternatural truth? If so, what then, became of his supposed allegiance to his government, and his duty to protect the Governor? Are these two allegiances conflicting, or are they complimentary? For surely, one cannot carry both the burden of protecting a life while at the same time being intent on ending that is very same life.

Concerning Osama bin Laden, if Pakistan truly was committed to fighting terrorism, how can one explain that bin Laden was able to hide in Pakistan for so long without being noticed? Is incompetence an issue, or is there something more sinister working at hand? Again, how do allegiances factor in to all of it? To simply answer that these questions are philosophical and/or enigmatic in nature is neither useful, nor is it particularly interesting. Therefore, the time has come for a more direct analysis concerning the nadir of terrorist organizations. In order to do so, this paper argues that a micro-level understanding of terrorists organizations is just as important as understanding the macro-level implications that they ultimately produce. We begin with a discussion of the evolution of terrorist organizations in Pakistan, all the while making linkages between these groups and the supposedly opposing Pakistani security apparatus - in particular, the ISI. From here, we will be better able to understand how loyalties become intermingled, and can lead to the paradoxical questions that have arisen out of the Governor Taseer assassination, and the hiding of Osama bin Laden on Pakistani soil.

\section{Islamic Extremism and Terrorism in Pakistan}

In Pakistan, as in other nations of the Muslim world, Islamist extremists have continually strengthened their influence in the Pakistani government and military. Most notably, the Taliban has developed a symbiotic relationship with Pakistan's infamous Inter-Services Intelligence, ISI [2], both inside Pakistan and over its borders with Afghanistan and India. During the Soviet occupation of Afghanistan in the 1980s, the United States' Central In- 
telligence Agency and the ISI nurtured the Taliban and the Haqqani network. This relationship has existed for several decades, but as the U.S. attempted to drive the Taliban from Afghanistan after the Soviet occupation of the country, ISI was waiting with "open arms" in Pakistan for their associates. The Haqqani network now operates out of Pakistan and maintains ties with the Taliban in Afghanistan. Such ties have been known by U.S., British, Afghan and Indian officials, but Pakistan continues to deny a current link with the Taliban.

Throughout its comparatively short history since gaining independence in 1947, Pakistan has witnessed decades of political infighting resulting in unrest, wars with India, several military coups, and long periods of military rule. It is clear, looking at events as they have unfolded in Pakistan in recent years that Pakistani society and its government have been adopting and implementing a more fundamentalist interpretation of Islam. When analyzing reports published by organizations such as the U.S. State Department, the CIA, Amnesty International, Human Rights Watch etc. that study such trends and their consequences, it becomes clear that Pakistan, as well as some of its neighbors, is moving in the direction of becoming an Islamic fundamentalist state.

The growth of Islamic fundamentalism affects not only society in general, but also the government. Pakistan is currently in a state of turmoil as the Pakistani Taliban militants have increased their presence throughout the country along with the consequential threat of destabilization of the Pakistani government. This has led to an atmosphere throughout the country of popular suspicion regarding the political legitimacy of the government. Recognizing that that Pakistani government, in fact, has been supporting Afghan Taliban militants for decades, places the current state of the country in a new light. Pakistan's ISI has strong ties.

\subsection{Inter-Services Intelligence}

The Inter-Services Intelligence (ISI), formally called the Directorate for Inter-Services Intelligence, is Pakistan's principal intelligence service. Pakistan's other branches of intelligence include the Intelligence Bureau and the Military Intelligence. While the ISI is responsible for preparing a national security valuation for the Pakistani government, it is most known for its role during the Soviet occupation of Afghanistan and the 1990s civil war in the country. The military intelligence that the ISI gathered was primarily used to support the mujahideen in the 1980s and the Taliban, which grew from the mujahideen, in the 1990s.

A military agency, as is the ISI, is defined as an organization of the military that acquires and analyzes information that is of strategic importance [3]. Often, this information is used to learn about the enemy. With such a definition, Pakistan's military agency, Inter-Services Intelligence (ISI), should be acquiring information about the Afghan Taliban to be tactically used to prevent the Taliban from the present-day violence and attacks; however, ISI and the Taliban have developed strong ties with one another. The relationship between the Taliban and the ISI in is not one of hierarchy; rather, the ISI has a role:

[A]s the provider of sanctuary, and very substantial financial, military and logistical support to the Insurgency, the ISI appears to have strong strategic and operational influence-reinforced by coercion” [4].

Since the emergence of the Taliban in Afghanistan, Pakistan's government has seen the group as strategically important. Whether to have political influence on the Afghan government or to have economically significant trade routes through Afghanistan, Pakistan has, especially through the ISI, been a major force in the growth and strength of the Taliban. But, according to Matt Waldmen, and many others across the globe,

Pakistan appears to be playing a double-game of astonishing magnitude. The conflict has led to the deaths of over 1000 American and 700 other foreign military personnel; thousands of Afghan soldiers, police, officials and civilians; and an unknown number of Afghan, Pakistani and other foreign insurgents. It has already cost America nearly $\$ 300$ billion, and now costs over $\$ 70$ billion a year (Belasco, 2009). As a Haqqani commander put it: "Of course Pakistan is the main cause of the problems [in Afghanistan] but America is behind Pakistan" [4].

In order to understand why the Pakistani government has had a hand in the way the Taliban has operated over the years, it is necessary to look at the origin of the relationship between the ISI and the Taliban, beginning as far back as the 1980s.

\subsection{Origin of Inter-Services Intelligence and Taliban Ties}

The relationship between Pakistan's Inter-Services Intelligence agency and the Taliban took roots during the 
Soviet occupation of Afghanistan in 1979. Many nations, particularly the United States and Saudi Arabia, had given billions of dollars to Afghanistan's mujahedeen, which would later develop into the Taliban, to fight the Soviets. It was Pakistan's ISI that facilitated the allocation of these hefty funds, although discriminately among the tribes in Afghanistan [5].

By the time the Taliban was emerging in 1994, ISI was supporting Hezb-e-Islami, which had been led by Gulbuddin Hekmatyar. In his book, Taliban, Ahmed Rashid describes an interview he had in 1999 with an advisor of Mullah Omar, a warlord in Afghanistan, illustrating the ISI’s financial support of Hekmatyar:

"Hikmetyar had 5 percent of the popular support but 90 percent of the military aid from the ISI. We were never recognized but, with the arrival of the Taliban, the support of the people of Afghanistan fell into our lap" [6].

However, when Hekmatyar suffered losses in 1994, ISI looked elsewhere for a group to support, all the while, keeping Pakistan's interests in mind. When the Taliban reached the Afghan-Pakistan border, the group seized Hekmatyar's bastion: here was the ISI's new team. The ISI allowed the Taliban to take its depot of weapons and ammunition to continue the Taliban's takeover of Afghanistan [5].

As the Taliban conquered cities in Afghanistan in 1995 and 1996, albeit suffering defeats along the way, Afghanistan's President at the time, Burhanuddin Rabbani, gained regional support against the Taliban. Neighboring countries did not want to live with a Taliban-ruled Afghanistan next door. In reaction to the regional support of Rabbani, Pakistan bolstered its support of the Taliban. Pakistan’s Prime Minister, Benazir Bhutto "even tried to convince the U.S., which had an interest in curbing Iran, to support the Taliban", but with no success [5]. Meanwhile, Pakistan continued to send Pakistani men with weapons to fight alongside Taliban rebels. Additionally:

"Pakistan provided diplomatic support, organized training for Taliban fighters, some of whom it had itself recruited, planned and commanded offensives, delivered ammunition and fuel and on several occasions apparently got directly involved in combat support. Undoubtedly, the Pakistani army and intelligence agencies, with the ISI at the forefront, made a vital contribution to the Taliban becoming a highly effective military force. The covert support of the Taliban by the ISI came from the corps headquarters in Peshawar. To give an example: a contact person deemed trustworthy by the U.S. consulate in Peshawar in October 1996 reported the border crossing from Pakistan into Afghanistan of an ISI convoy, consisting of 30 - 35 ISI trucks and 15 - 20 fuel trucks, at Torkham. The ISI itself in late 1996 estimated the total Pakistani aid to the Taliban to be as high as 20 million rupees. A number that may well be set too low. Two years later, a Pakistani source of the U.S. State Department put the support of the Pakistani government for the Taliban at about a million dollars every few months" [5].

Even following Pakistan's change in President in 1999, when Pervez Musharraf led a coup d'état, the Taliban still thrived with the backing of the Pakistani government and the ISI. But after the terrorist attacks on September 11, 2001 in the United States, and a U.S. occupation of Afghanistan to drive out the Taliban, the Pakistani government suddenly switched sides and appeared to be a U.S. ally. On the surface, Pakistan's ISI pledged to fight the Taliban alongside the U.S. troops, but in reality, the agency continued to send weapons and fuel to the Taliban in Afghanistan. In this conflict, the U.S. was confronting not just Mullah Omar's Taliban, but also Hekmatyar's Hezb-e-Islami and the Haqqani network. The U.S. accomplished ousting the groups for a short time; subsequently, Hekmatyar and Jalaluddin Haqqani received sanctuary in Pakistan and were able to restore their groups.

The resignation of President Musharraf in August 2008 added to the uncertainty that Pakistani citizens face with regard to judicial fairness, and guarantees of personal and societal protection by the military or civilian police authorities. The assassination of former Prime Minister Benazir Bhutto in December of 2007 still contributes to the unrest and suspicions of the Pakistani people. It is widely suspected that Baitullah Mehsud, killed by a U.S. drone strike in 2009 [7], a religious extremist orchestrated her murder. Suspicions of collusion in her murder by ISI security forces, and government cover-ups are nevertheless ongoing at the time of this writing. The same forces are also thought to have planted the bombs, which killed over 130 people when Mrs. Bhutto returned to Pakistan in October 2007. Recently in August 2013, Pervez Musharraf was indicted on charges of murder, conspiracy to murder, and the facilitation of murder in relation to the death of Benazir Bhutto [8].

Despite or perhaps due to Pakistan's alignment with the West in the war on terror, Western nations have little 
or no impact on social behavior in Pakistan. Pakistani society and Muslim societies in general, have been swept by anti-Western sentiments after the September 2001 attacks in the U.S. Examples of this atmosphere in Pakistan include the beheading of American Journalist Daniel Pearl, the numerous assassination attempts against former President Musharraf (because of his perceived ties with the U.S.), and the strict implementation by the government of Pakistan's blasphemy laws. Anger towards the West has been further fueled by developments along Pakistan's border with Afghanistan.

Beginning in June 2008, 11 Pakistanis were killed by U.S. airstrikes as they were caught in a firefight between Coalition Forces and Taliban fighters. In response, the Pakistani government publically condemned the U.S. military, and according to the New York Times, "Local tribesmen with rocket launchers and Kalashnikov rifles gathered Wednesday near the checkpoint that was reportedly attacked by the airstrikes to show their outrage after the attack" [9].

Amid these examples of extreme violence occurring throughout Pakistan, tensions continue to mount as the U.S. has been embarking on raids inside Pakistan. Since August 2008, there have been over 100 American strikes in Pakistan, most notably on November 1, 2008 when missiles fired by a remotely piloted American aircraft hit two villages near the Afghan border, killing 27 people. According to the Associated Press, "[t]he attacks have angered many Pakistanis and put strains on a seven-year alliance between the United States and Pakistan, where rising violence is exacerbating economic problems and threatening the country's stability” [10]. U.S. attacks, largely carried out by drone aircraft, continued into 2009 and 2010.

Furthermore, the killing of Osama bin Laden within Pakistani territory has only strained the already weak alliance between the United States and Pakistan. In May 2011, the Pakistani Parliament passed a formal resolution describing the U.S. operation in Abbottabad (which killed bin Laden) as violation of Pakistan's sovereignty, and called for a review of Pakistan's relationship with the United States [11]. A few months later, on November 26, 2011, a U.S. led NATO attack resulted in the deaths of 24 Pakistanis along the Afghan border [12].

Reports over the past few years claiming that the Pakistani government is making progress against Taliban strongholds can be very misleading. By no means should they be taken to mean that the threat posed by the Taliban has significantly subsided. While military forces have moved into volatile regions (particularly the Swat Valley) and have allowed the return of a small number of refugees, the government cannot actually guarantee stability in the region, as demonstrated by the fact that the Taliban has invaded and occupied the Swat Valley twice since 2007.

Moreover, it is clear the Pakistani police and military continue to lack effective control over the Taliban despite claims they have achieved victory in parts of the country. According to the U.S. State Department's Human Rights Report published in 2014, "Police often failed to protect members of religious minorities, including Christians, Ahmadiyya Muslims, and Shia Muslims, from attacks” [13]. Recent years have only shown that the Taliban has continued to strengthen its forces in spite of claims to the contrary by its opponents. Particularly concerning the Swat Valley, the past few years have proven to be nothing more than a "seesaw" of power between the Pakistani government and Taliban forces resulting in instability and a crumbling infrastructure in the Valley. It is a scenario in which the Taliban thrives.

Over the past several years alone, socio-political conditions in Pakistan have deteriorated to the point that it is a nation in crisis. The government is in turmoil, which has opened wider the doors for other Islamist extremists and terrorists to violently impose their will on Pakistani society. In Pakistan today, religious minorities and apostates are officially discriminated against and persecuted by the government by way of its laws that restrict religious freedom and generally so by Pakistan's majority Sunni Muslim society. The religious tenets of fundamentalist Islam give support to the powerful socio-political positions of imams in Pakistan and to Pakistan's various tribes to make and impose their decisions according to their strict interpretations of Islamic law. They are overtly and covertly supported by elements in the military and the ISI, who support the harsh punishment of accused apostates, blasphemers, Muslim "deviants" and individuals perceived to be spies for Western powers, especially the United States.

The United States government has declared Pakistan an ally in the fight against terrorism in Afghanistan and Pakistan, but many U.S. officials have openly stated that Pakistan's ISI has a relationship with the Taliban. Although the U.S. is fighting an idea, terror, rather than a sole entity, officials contend that discounting the ISI and Taliban relationship hinders progress. This is especially true as the U.S. downplays the role of the ISI in the growth of the Taliban, providing billions of dollars in aid and military support to Pakistan over the years. Nonetheless, Pakistan is not the only player in its double-game. The U.S. also states one thing, and acts out another. 
The U.S. deems Pakistan an ally, but has killed innocent civilians with drones in Pakistan. If Pakistan were sending drones to kill militants and the aftermath included destroyed U.S. property and U.S. civilian casualties, Pakistan would never be considered an ally of the U.S. Pakistan would be an enemy. When Robin Lustig, a journalist for the BBC Network, spoke with General Asad Durrani, a former Director General of the ISI, Durrani echoed this actuality:

"Pakistan should be supporting the anti-US opposition in Afghanistan, he said. If the US insists on launching drone strikes against targets in Pakistan, sometimes killing innocent Pakistani civilians, then the US and Pakistan are in a state of what he called 'low-intensity conflict'” [14].

And veteran intelligence analyst Bruce Riedel maintains that if the U.S. were to stop the drone program:

"Al-Qaeda will regenerate rapidly in Pakistan. Its allies like the Taliban and Lashkar-e-Taiba will help it to rebuild. The ISI will either turn a blind eye or, worse, a helping hand" [15].

For the Pakistani public eye, Prime Minister Nawaz Sharif has criticized the drone program and railed against U.S. drone strikes as an affront to Pakistani sovereignty while advocating for talks with the TTP. Yet, the International Crisis Group notes, "Ample evidence exists of tacit Pakistani consent and active cooperation with the drone program”. Pakistan's leadership seeks greater say over targeting, the ICG says, "often to punish enemies, but sometimes, allegedly, to protect militants with whom the security services have cooperative relations-including elements of the Haqqani Network and Taliban" [15].

Both the U.S. and Pakistan appear to be playing one another at a time when there is no room for games. The Taliban continues to orchestrate and execute attacks in Afghanistan and Pakistan and U.S. forces are placed in danger whilst Pakistan is supporting the enemy. The Haqqani network, a semiautonomous group allied with the Afghan Taliban and acting as mediator for the Pakistani Taliban, "presents the greatest threat to security forces", General Joseph Dunford, the commander of the U.S. Forces in Afghanistan, stated on March 14, 2014 [16]. The U.S. declared the Haqqani network a Foreign Terrorist Organization only one and a half years ago. And one year prior to that designation, in September 2011, the former US Joint Chiefs of Staff, Admiral Mike Mullen, warned of the Haqqani network, assuredly insisting that the Haqqanis act as a "veritable arm" of the Pakistani military intelligence agency, the ISI" [14]. Pakistan is likely supporting the Haqqani network to create leverage against India and Afghanistan.

Admiral Mike Mullen is not alone in his view of the ISI. Officials in the British government have also made assertions that the ISI has ties with the Taliban. Specifically, British officials have blamed the ISI for bombings in their country:

In fall 2006, a leaked report by a British Defense Ministry think tank charged, "Indirectly Pakistan (through the ISI) has been supporting terrorism and extremism whether in London on 7/7 [the July 2005 attacks on London's transit system], or in Afghanistan, or Iraq" [17].

Moreover, a BBC article reported that a London School of Economics paper revealed that Taliban field commanders suggested that ISI intelligence agents even attend Taliban supreme council meetings—and that support for the militants was "official ISI policy" [18].

While such a claim cannot be confirmed as it is stated by Taliban field commanders, it is not of benefit to the Taliban to falsely state that ISI agents have been attending Taliban meetings. If for no other reason, the Taliban may be revealing the ISI's commitment to the Taliban to demonstrate that the militants are receiving support from a government agency, legitimizing their purpose. In addition to the British Defense Ministry think tank, current British Prime Minister, David Cameron, has also publicized his concern of ISI's ties with the Taliban, "He accused the country of 'looking both ways' when it came to fighting terrorism and suggested that elements in Pakistan were guilty of promoting the "export of terror" [18].

Like some U.S. and British officials, the Afghan government is not in the dark when it comes to the reality of ISI and Taliban cooperation. Afghanistan and Pakistan have had a relationship since Pakistan acquired independence in 1947. Two governments have shared intelligence information and have attempted to confront the Taliban together. However, Afghan officials are acknowledging that their neighboring brother has been conspiring behind closed doors. According to Bajoria and Kaplan, of the Council on Foreign Relations:

In June 2008, Afghan officials accused Pakistan's intelligence service of plotting a failed assassination at- 
tempt on President Hamid Karzai; shortly thereafter, they implied the ISI's involvement in a July 2008 attack on the Indian embassy. Indian officials also blamed the ISI for the bombing of the Indian embassy. Pakistani officials have denied such a connection [17].

The Pakistani government always incessantly denies any connection to the Taliban. Not surprisingly so, it is in Pakistani's interest to keep up the charade. If Pakistan were to admit to maintaining ties with the Taliban, the U.S. would cease to provide billions of dollars in aid to Pakistan. Pakistan's game is in plain sight, especially in Afghanistan. Omer Aziz, of The Diplomat, highlights the game that Pakistan has been playing for years:

For four decades, Pakistan's spy-generals have played Afghanistan like a powerful chip in a consequential game of poker. They know the important local militants, have open channels to their favorite groups, and regularly play various groups against the Western coalition. The twin justifications for the aggressive intervention in Afghan affairs are India and American withdrawal. Since Pakistan's humiliating dissection at Indian and nascent Bangladeshi hands in 1971, Islamabad's doctrine vis-à-vis Afghanistan has been known as strategic depth. For the ISI, Afghanistan is to be a safety net should the delusional prediction that India will invade a weaker Pakistan actually come true [19].

Pakistan fears India, sometimes making decisions in a state of paranoia, and has been willing to maintain relations with the Taliban to ensure the country has leverage in the future. Maintaining ties with militants that are anti-U.S. and also against the Afghan government may prove disastrous for Pakistan. In a state of turmoil, Pakistan is fighting militants in its own cities. If the Pakistani government allows the ISI to continue waging a false fight against the Taliban, the country may lose support from the rest of the world. Keeping the Taliban as a friend will ultimately create many enemies for Pakistan, placing an already volatile nation on the edge of a cliff.

\section{Understanding Taliban and ISI Ties: A Network Approach}

Understanding the relationship between the ISI and the Taliban requires a deeper sociological perspective, particularly in showing how such supposedly diametrically opposed actors actually demonstrate a symbiotic relationship. In order to conceptualize this paradox, it is necessary to look from the ground up, rather than the topdown, as many in the field have attempted to do.

To begin, Pakistan finds its roots in tribal society. In this society there are two key aspects that take primacy above all else: religion and family. Both are products of socialization, meaning that from birth, an individual is given the tools to develop individual and collective identities. This includes teachings from parents, educators, and from religious leaders as well. Additionally, individuals are heavily influenced by their surroundings and culture. It is here that we begin to see how society, on a macro level, operates, and how we are able to enforce our understandings of right and wrong, just and unjust. From an early age, we are taught to develop networks. Indeed, the core family is a network in and of itself, where individuals (fathers, mothers, sisters, brothers) learn their roles within the network. The network extends, of course to other close relatives, including grandparents, aunts and uncles, and cousins. These can be referred to as natural networks, as they are "built in" to an individual's life upon birth.

As we grow and interact with society, we begin to enhance our natural networks with the in the inclusion of friends, fellow students, fellow members of our religious congregation, and so forth. It is then that informal networks, not unlike natural networks are developed. As argued in the author's previously published paper, "Engineering Social Capital in the Middle East: Rebuilding Trust" [20], trust is essential to building these networks, which eventually translates into accumulating social capital. The author argued that the existence of trust allows for the buildup of productive ties, while the absence of trust significantly diminishes the possibility of cooperation. Once trust is established-through systematic cooperation and the building of meaningful ties, organizations on a broader scale can begin to solidify.

Based on the solidification of trust, informal networks and organizations are established and become fluid. In his analytically sound piece, "The Utility of Informal Networks to Policy-Makers", Alexander Evans points to the nature of informal networks, and how they lead to trust building and lead into the establishment of cohesive social organizations [21]. He argues that it is impossible to understand how governments and societies operate without first grasping the nature of informal networks. Evans writes:

Informal networks, and unofficial ways of doing things, are all around us. Culture, as much as rules, shape 
organizations and the incentives that apply to people within them... Informal networks and cultures guide the way in which organizations function; in particular how information is transmitted within them. Power, prestige, influence and trust are all strongly influenced by the nature of organizational culture; social norms are powerful, and although not unchanging, can provide significant insights into where power is located and how decisions are reached. Informal networks take many forms, but often draw on ties of kinship, friendship, or social obligation [21].

Turning our attention to the specific case of Pakistan, Evans points to sifarish (meaning “recommendation”). In Pakistan, sifarish is a system akin to nepotism, where individuals holding positions in high places (including in government and business) are "obligated", due to their informal networks, to offer open positions first to members of their kinship group and loyal friends. Sifarish is also tied to biraderi. Meaning brotherhood, biraderi provides the basis for the larger kin group in Pakistani society. In essence, all men that can trace their ancestry to one common male ancestor are known to belong to the same biraderi. Biraderi is essentially a combination of natural networks (associated with birth) and informal networks, grounded in an expansion of natural networks. Biraderi, given its ties to ancestry, is not beholden to internationally recognized borders. For example, a Pakistani individual living in the United States will always be tied to his/her biraderi and others within it, no matter where they reside.

Taking sifarish and biraderi into consideration, we can begin to understand the paradoxical relationship between the ISI and groups such as the Taliban and al-Qaeda. The issue really becomes a question of loyalty. We remember that individuals within Pakistani society are loyal first to their religion (Islam) and their kinship group. Government and public society are secondary, and loyalties to such organizations are still conditioned by trust and how an individual can benefit from each of the competing organizations. In his analysis of tribal groups in Pakistan entitled "Honor the Baloch, Buy the Pushtun”, Paul Titus examines the quasi-state of the tribal regions and how the government has to take into consideration the power of networks in dealing with them. Titus argues, "People approach new situations with the cultural categories and institutions with which they are familiar and with which they have had success in the past. Thus features of social life that gave rise to particular generalizations about Pushtun and Balaoch in the colonial era persist today” [22].

In brief, Titus argues that cultural, historical, and even individual ties are important to understanding how groups cooperate or come into conflict. Individuals naturally gravitate to what is comfortable with him or her, and groups that support their worldviews. Therefore, we often times see that for some, the Pakistani government offers the best possibility to enhance security as well as individual and collective goals. At the same time however, groups such as the Taliban and al-Qaeda present a front that is attractive in terms of local stability and groups that are in line with religious needs. These needs are not lost on the Pakistani government and the ISI. As members of the community themselves, they realize the importance of informal and formal networks, which is why they have historically attempted to co-opt both the Taliban and al-Qaeda, in order to put forth a united front, as well as to preserve power. This was the case during the Zuia ul-Haq regime, as well as the Musharraf regime.

Both governments, as well as the current government could not overlook the public sympathy for organizations such as the Taliban and al-Qaeda, particularly when these groups were more in line with their needs, and provided benefits to their own networks that the government simply could not supply. In his piece entitled, "Passive Supporters of Terrorism”, Daniel Byman discusses the general respect Pakistanis had for Osama bin Laden. Byman argues:

Bin Laden and his followers enjoyed genuine popular support in Pakistan. Many poorer Pakistanis saw him as a modern-day Robin Hood, a man who combined both faith and action. Many middle- and upper-class Pakistanis also support al-Qaeda, seeing it as one of the few Muslim movements that successfully stands up to the United States. Reflecting this popularity, pilgrims visit the sites where al-Qaeda members died, and those who cooperate with the Pakistani government against the organization are often ostracized [23].

Byman's account concerning bin Laden and the support he received in greater Pakistani society should not be minimized. From a sociological perspective, it helps us to constantly remember that every individual is beholden to various, often seemingly conflicting networks, ranging from familial, to political, to spiritual. Based on these networks, individuals must choose where to place their loyalties. In the case of bin Laden, many Pakistanis sought him out (and his mission) as a way to fulfill multiple needs that were not necessarily conflicting with their spiritual convictions and political ideologies. All the while, they were also able to uphold their honor in 
terms of societal respect, as the "Bin Laden movement" and the ideology it promoted spanned across multiple networks. On the other hand, we had individuals within government that outwardly opposed bin Laden and his actions. As Byman notes, these individuals made the difficult choice of standing against bin Laden, while justifying their decision in the face of becoming outcasts from their greater communities.

\section{Conclusion}

When we understand loyalty in terms of natural and informal networks, we can begin to further understand how terrorism in Pakistan is able to flourish, and how incidents such as the assassination of Punjab Governor Salman Taseer at the hands of his own bodyguard, and the hiding of Osama bin Laden are possible. To be certain, there are those who are loyal to the government, as well as to the ISI, and are committed to the fight against terrorism. However, one cannot neglect to take into consideration the importance of natural and informal networks and how they impact both individual and collective behaviors. Only when we can fully grasp the importance of these networks and how they translate into action can we begin to fully address the paradox of multiple loyalties in Pakistan. Once we begin to understand the source of the nature of terrorism in Pakistan - which lies in network formation - we can then make more socially attentive policymaking decisions in our efforts to combat terrorism not just in Pakistan, but across the region.

\section{References}

[1] Sageman, M. (2004) Understanding Terror Networks. University of Pennsylvania Press, Philadelphia.

[2] (n.d.) U.S. Says Pakistan’s ISI Using Group for Proxy War Reuters. http://www.reuters.com/article/2011/09/21/us-pakistan-isi-idUSTRE78K16420110921

[3] (n.d.) Military Intelligence Agency-Definition of Military Intelligence Agency by The Free Dictionary. http://www.thefreedictionary.com/military+intelligence+agency

[4] Waldman, M. (2010) The Sun in the Sky. http://www.aljazeera.com/mritems/Documents/2010/6/13/20106138531279734lse-isi-taliban.pdf

[5] (n.d.) The Pakistani Godfather: The Inter-Services Intelligence and the Afghan Taliban 1994-2010. Small Wars Journal.

http://smallwarsjournal.com/jrnl/art/the-pakistani-godfather-the-inter-services-intelligence-and-the-afghan-taliban-199 $\underline{4-2010}$

[6] Rashid, A. (2000) Taliban: Islam, Oil and the New Great Game in Central Asia. I.B., London.

[7] (n.d.) Pakistanis Are Indicted in Benazir Bhutto’s Killing. NYTimes.com. http://www.nytimes.com/2011/11/06/world/asia/7-pakistanis-are-indicted-in-benazir-bhuttos-killing.html

[8] (n.d.) Musharraf Accused of Benazir Bhutto Murder Case. Pakistan Today. http://www.pakistantoday.com.pk/2013/08/20/news/national/musharraf-accused-of-benazir-bhutto-murder-case/

[9] (n.d.) Pakistan Angry as Strike by U.S. Kills 11 Soldiers. NYTimes.com. http://www.nytimes.com/2008/06/12/world/asia/12pstan.html?_r=1\&hp\&oref=slon

[10] (n.d.) Missile Attacks, Apparently by U.S., Kill 27 in Pakistan, Including Qaeda Operative. NYTimes.com. http://www.nytimes.com/2008/11/01/world/asia/01drone.html?_r=1\&scp=39\&sq=Pakistan\&st=nyt\&oref=slogin

[11] (n.d.) BBC News_Pakistan Profile-Timeline. http://news.bbc.co.uk/2/hi/south_asia/country_profiles/1156716.stm

[12] (n.d.) BBC News—Pakistan Orders Nato and US Review after Deadly Border Strike. http://www.bbc.co.uk/news/world-asia-15905777

[13] (n.d.) Country Reports on Human Rights Practices for 2013. http://www.state.gov/j/drl/rls/hrrpt/humanrightsreport/index.htm\#wrapper

[14] (n.d.) BBC—World Tonight: US and Pakistan: Allies or Enemies? http://www.bbc.co.uk/blogs/legacy/worldtonight/2011/09/us_and_pakistan_allies_or_enem.html

[15] Council on Foreign Relations (n.d.) Backgrounder. www.cfr.org/pakistan/pakistans-new-generation-terrorists/p15422

[16] (n.d.) Haqqani Network a Threat to Afghan Election: US Commander. Pakistan. Dunya News. http://dunyanews.tv/index.php/en/Pakistan/215253-Haqqani-network-a-threat-to-Afghan-election-US-co

[17] Kaplan, E. (2011) Council on Foreign Relations. www.cfr.org/pakistan/isi-terrorism-behind-accusations/p11644

[18] (n.d.) BBC News—Pakistan's Shadowy Secret Service, the ISI.

http://www.bbc.com/news/world-south-asia-13272009 
[19] Aziz, O. (2014) The ISI’s Great Game in Afghanistan | The Diplomat. http://thediplomat.com/2014/06/the-isis-great-game-in-afghanistan/

[20] Gabbay, S.M. and Leenders, R.T. (2001) Social Capital of Organizations. JAI, Amsterdam.

[21] Evans, A. (2010) Terrorism, Security, and the Power of Informal Networks. Edward Elgar Publishing, Northhampton, 13-14.

[22] Titus, P. (1998) Honor the Baloch, Buy the Pushtun: Stereotypes, Social Organization and History in Western Pakistan. Modern Asian Studies, 32, 657-687. http://dx.doi.org/10.1017/S0026749X98003023

[23] Byman, D. (2005) Passive Sponsors of Terrorism. Survival, 47, 117-144.

http://dx.doi.org/10.1080/00396330500433399 
Scientific Research Publishing (SCIRP) is one of the largest Open Access journal publishers. It is currently publishing more than 200 open access, online, peer-reviewed journals covering a wide range of academic disciplines. SCIRP serves the worldwide academic communities and contributes to the progress and application of science with its publication.

Other selected journals from SCIRP are listed as below. Submit your manuscript to us via either submit@scirp.org or Online Submission Portal.
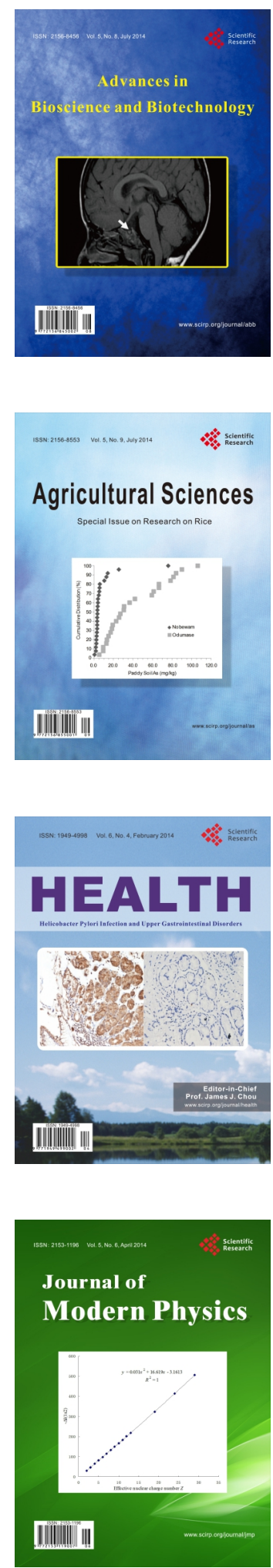
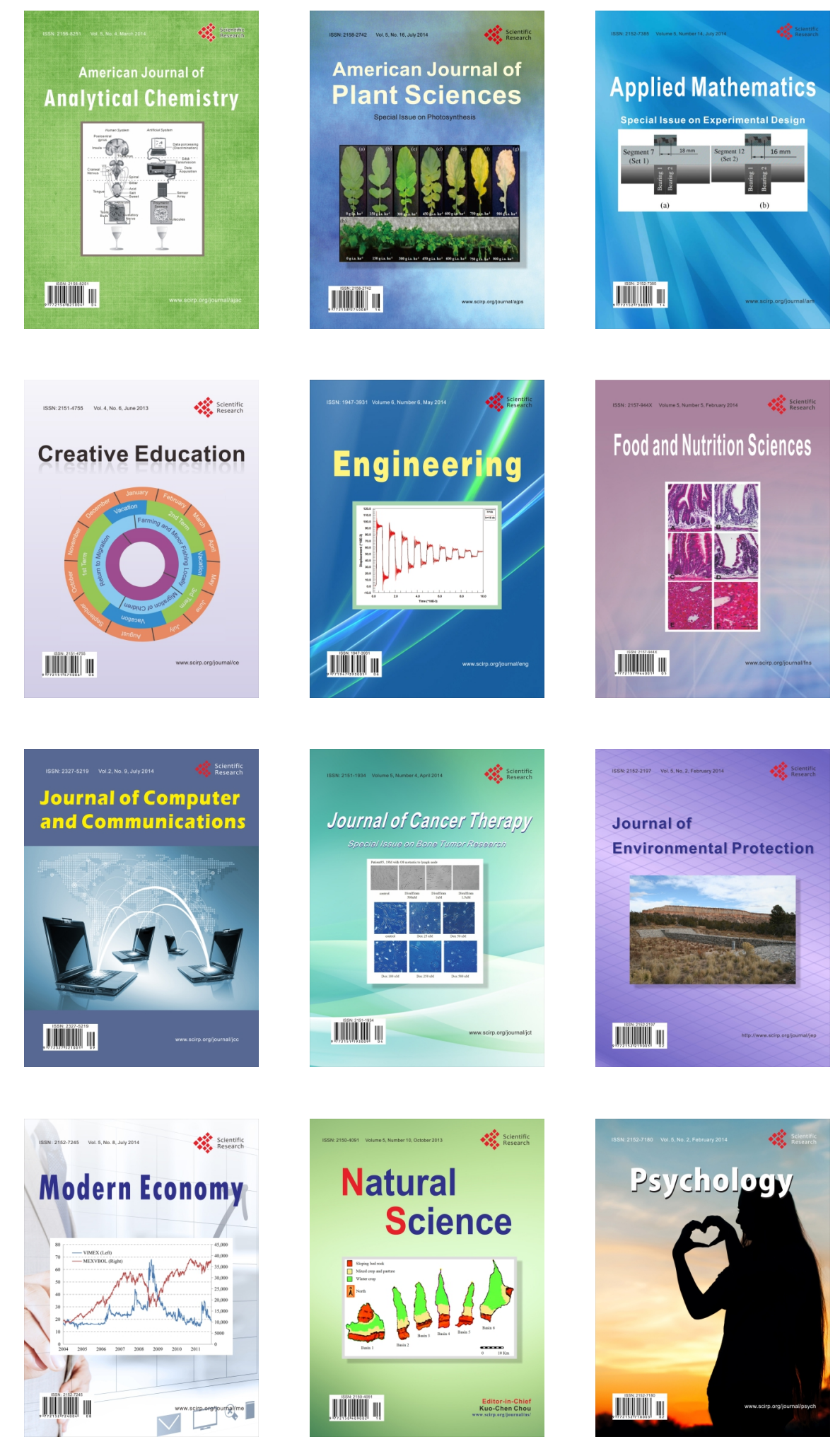